Sohannessen, Janne Bondi \& Kristin Hagen (red.) Leksikografi og korpus. En hyllest til Ruth Vatvedt Fjeld, Oslo Studies in Language 11(1), 2020. 7-30. (ISSN 1890-9639 / ISBN 978-82-

\title{
EN MER INKLUDERANDE LEXIKOGRAFI - BORTOM FRÅGAN OM KVINNOR OCH MÄN
}

\author{
EMMA SKÖLDBERG
}

\section{SAMMANFATTNING}

I artikeln behandlas ordböcker ur ett genusperspektiv. I första hand diskuteras, utifrån befintlig genuskritisk forskning, innehållet i det enspråkiga verket Svensk ordbok utgiven av Svenska Akademien (SO, 2009). Vidare presenteras resultaten av en undersökning som gäller användningen av substantiven tjej och kille i SO:s språkprov. Dessa resultat utgör underlag för resonemang kring några av de förändringar som är aktuella inför nästa upplaga av ordboken, som är under utarbetande.

\section{[1] INLEDNING}

Studier av ordböcker ur ett genuskritiskt perspektiv visar, som Fjeld (2001:1213) har konstaterat, att "kvinnene og deres språkbruk ofte blir dårlig behandlet, selv om ikke alle ordbøker er direkte sexistiske". Kritik har riktats mot bl.a. svenska verk, exempelvis Svensk ordbok utgiven av Svenska Akademien (SO, 2009). En av de frågeställningar som kritiska läsningar av ordböcker väcker är om ordböcker såsom SO upprätthåller, eller kanske t.o.m. befäster, stereotypa skillnader mellan könen.

I det följande redogör jag kortfattat för det lexikografiska forskningsläget ur ett genusperspektiv. Därefter följer en kort diskussion om olika typer av ordböcker och vilken eller vilka roller de förväntas spela i förhållandet till språket och det omgivande samhället. Vidare diskuterar jag, utifrån befintlig genuskritisk forskning, innehållet i SO (2009), som tjänar som utgångspunkt för denna artikel. Därpå följer en mindre empirisk studie baserad på innehållet i SO (2009). Studien, som gäller användningen av substantiven tjej och kille i språkprov i ordboken, utgör underlag för vidare resonemang kring några av de förändringar som är aktuella inför nästa upplaga av verket, som är under utarbetande.

De frågor som tas upp i artikeln är näppeligen enkla att besvara och jag vill förutskicka att artikeln inte innehåller något uttömmande facit. I den meningen innehåller följande text således fler frågor än svar. De problematiserande resonemang som förs torde dock visa på den komplexitet som många av dessa frågeställningar har. 
Innan redogörelsen för forskningsläget följer nu en kortfattad presentation av den aktuella ordboken. SO kom ut i tryckt format år 2009 och i form av appar 2015. SO är en vidareutveckling av Svensk ordbok (SOB 1986) och Nationalencyklopedins ordbok (NEO 1995-96), och den bygger på en databas som utarbetats och vidareutvecklas vid Institutionen för svenska språket, Göteborgs universitet. Huvudredaktör för ordboken var professor Sven-Göran Malmgren. SO är en definitionsordbok som avser, bl.a. genom betydelsebeskrivningar och språkexempel, att i första hand beskriva svenskt samtidspråk. Vidare är SO en korpusbaserad ordbok. De korpusar som användes under arbetet inför 2009 års upplaga (och dess föregångare) innehöll huvudsakligen svenska dagstidningar och romaner, dvs. etablerat, redigerat skriftspråk (se Inledning, 2015:XII; se vidare nedan). Det är värt att framhålla att de språkprov som ges oftast är redigerade. Korpusarna utgör ett viktigt stöd när det gäller att finna illustrativa exempel men många autentiska språkanvändningar har modifierats innan de lagts in i ordboksdatabasen (se vidare bl.a. Hult 2010 för en diskussion kring autentiska vs. redigerade språkprov och tankarna bakom SO:s exempelgivning).

Tillsammans med Akademiens andra två ordböcker, rättskrivningsordboken SAOL och den historiska ordboken SAOB, är SO tillgänglig via webbplatsen svenska.se. SO har genom ordboksportalen fått större spridning. Avståndet mellan redaktion och användare har tack vare portalen i förening med ordboksapparna minskat. Användare kan nu på ett enklare sätt än tidigare förmedla sina synpunkter på ordböckernas innehåll till lexikograferna.

\section{[2] GENUSKRITISKA STUDIER AV ORDBÖCKER}

Enligt Hageberg (1990:49-50) ökade intresset i slutet av 1960-talet för att närma sig språket på nya sätt. I kölvattnet av kvinnorörelsen på 1970-talet publicerades en rad forskningsartiklar m.m. om språk och kön och språk och makt (se även Epple 2000; Edlund et al. 2007: 47-54; Ishikawa 2013:222). Forskningsinriktningar som psykolingvistik och sociolingvistik etablerades därmed som egna kunskapsfält. Anmärkningsvärt nog kom emellertid inte innehållet i ordböcker - under denna tid eller under de kommande decennierna - att granskas eller ifrågasättas i någon nämnvärd omfattning.

Under de senaste decennierna, inte minst på 1990-talet, har det dock forskats kring nordiska ordböcker ur ett könsperspektiv (se exempelvis Hageberg 1990, Nikula 1997, Kram 1998, Fjeld 2015). Forskningsslutsatserna om nordiska ordböcker går i linje med iakttagelser i internationella lexikografiska studier av bl.a. Whitcut (1983), Epple (2000), Landau (2001), Ishikawa (2013), Moon (2014) och Arimbi \& Kwary (2016).

Hageberg (1990) problematiserar det sätt som kvinnor presenteras i norska 
ordböcker. Hon konstaterar bl.a. att kvinnor överlag är relativt frånvarande i verken och att närvarande kvinnor framställs de på ett onyanserat sätt. Hon ifrågasätter även varför antalet nedsättande benämningar på kvinnor är klart högre än nedsättande benämningar på män i lexikografiska verk.

Också Fjeld (2001) studerar norska ordböcker ur ett genusperspektiv. Hon konstaterar bl.a. att det ofta finns stora luckor i ordböckernas lemmauppsättningar vad gäller uppslagsord kopplade till bl.a. smink och kläder, kvinnliga kroppsfunktioner och traditionella kvinnosysslor. Fjelds forskningsgenomgång visar också att kvinnor i ordböcker ofta presenteras som om de vore avhängiga av män. De beskrivs generellt stereotypiskt exempelvis genom sina yrken (såsom sekreterare) eller genom de sysslor de ägnar sig åt (såsom dammsugning) (2001:11-13).

Nikulas studie (1997) visar i sin tur på en rad skevheter i språkprov som ingår i svenska SOB (1986). Hon konstaterar att sexism inte nödvändigtvis uppträder öppet i den meningen att kvinnor negligeras i exempelmeningarna eller att de omtalas som bihang till män. Det förefaller däremot finnas gott om exempel på dold och mera försåtlig diskriminering eller smygsexism. Kännetecknande för denna typ är, enligt Nikula, att kvinnan beskrivs som underordnad, passiv, som objekt, och bunden till de gamla könsrollsmönstren (1997:196). Vidare konstateras att kvinnor också ofta uppträder i exempel som är negerade och att de därför framstår som oförmögna i något avseende (t.ex. "en kvinna i karriären har inte tid med barn"). Denna typ av sexism är långt mindre iögonenfallande än när kvinnor omtalas med nedsättande beteckningar som ragata, satkäring och skvallermoster (se även Kram 1998; Edlund et al. 2007:179-205, 192-194).

Nikula (2008) har även studerat svenska ordboksillustrationer ur ett könsperspektiv och kommer då fram till att illustrationer främst gäller ord som hör hemma i en manlig värld. Enligt författaren är det en konsekvens av en allvarlig och grundläggande obalans vid valet av lemman.

De problem som lyfts fram ovan gäller främst enspråkiga ordböcker men också tvåspråkiga verk uppvisar brister ur genusperspektiv. Bl.a. har Pilke (2009) synliggjort den skeva bild av kvinnor och män i arbetslivet som återges i en större finsk-svensk ordbok från 1990-talet.

Genuskritiska studier av ordböcker kan och bör sättas in i ett större sammanhang. Studierna av manligt och kvinnligt i ordböcker och ordboksexempel har t.ex. tydliga beröringspunkter med undersökningar av innehållet i exempel som ges i grammatikböcker. Bland annat har Ohlander (1995) studerat exempel som återfinns i engelska grammatikor under en tidsperiod av 400 år. Lewandowski (2014) har å sin sida studerat innehållet i exempelmeningar i liknande böcker sedan 1970-talet och framåt. Enligt Ohlander (1995) speglar flertalet exempel i 
grammatikböckerna religiösa och politiska idéer under olika perioder. Exempelvis anspelar många äldre exempel på välkända teman i Bibeln. I yngre böcker kan exemplen istället gälla miljöfrågor, dvs. teman som, åtminstone 1995, kunde betraktas som okontroversiella. I äldre exempel beskrivs också män ofta som modiga och intelligenta medan kvinnor beskrivs som dygdiga och blygsamma. Det tycks emellertid som om vissa av dagens grammatiker strävat efter att bägge könen rent kvantitativt ska vara lika välrepresenterade i sina verk (Ohlander 1995:230-234; jfr Fjeld 2015). Under de senaste decennierna har det, enligt Lewandowski (2014), också skett en förändring vad gäller exemplens innehåll, bl.a. när det kommer till yrkesroller. Ohlander (1995) konstaterar dock avslutningsvis att den bild han målar upp kanske är väl konstruerad, inte minst ur ett feministiskt perspektiv och att grammatikernas exempel inte alltid är representativa med tanke på verkligheten: "Instead, they occasionally seem to indulge in some kind of virtual (...) reality, often amounting to wishful thinking, promoting what is, at a certain time, widely regarded as a good and political correct cause" (1995:234). Exemplen i grammatikböcker kan alltså inte alltid tas som intäkt för hur det ser ut i verkligheten.

Enligt Hageberg (1990:48) speglar återgivningen i bl.a. ordböcker det faktum att män genom historien haft mer makt. Det har lett till att ett manligt perspektiv varit förhärskande i språkvetenskapliga avhandlingar, läroböcker m.m. Vidare har ordboksredaktionerna genom tiderna dominerats av manliga medarbetare (se vidare Hageberg 1990:50-51 för en historisk genomgång av könsfördelningen bland lexikografer vid olika ordboksredaktioner i Norden). Många av de informanter som på olika sätt bidragit med språkligt material till ordboksredaktionerna har också varit män. Det har även varit en övervikt av manliga författare till de verk som ordboksredaktörerna excerperat ur (Hageberg 1990:51-54). Detta senare påstående stöds också av Mattisson (2006) som anlagt ett genusperspektiv på SAOB:s källor.

Hageberg påpekar dock att det visat sig att fler kvinnor på ordboksredaktionerna inte per automatik leder till högre grad av kvinnlig närvaro och jämlikhet $\mathrm{i}$ ordböcker (jfr Fjeld 2015:53). Hageberg (1990:59-60) konstaterar att ordboksredaktörer har större makt och möjlighet att styra innehållet i ordböckerna än de kanske är medvetna om. Ordboksförfattare (såväl kvinnliga som manliga) har ett stort ansvar när de definierar, väljer ut autentiska språkexempel och inte minst konstruerar egna språkprov.

Flera av de studier som nämns ovan är 20 år eller äldre och de gäller ofta äldre ordböcker och man hoppas förstås att det ser annorlunda ut i ordböcker av idag. Enligt Epple (2001), vars studie utgår från tvåspråkiga ordböcker, går det att se markanta skillnader i graden av medvetenhet om dessa frågor i äldre och mer 
nyutkomna verk (se även Landau 2001). Epples resultat kan dock inte åberopas som stöd för att allt är bra, fastän det har blivit bättre. En relativt nylig studie som ger besked om nutida verk är redan nämnda Fjeld (2015), som i en djupgående undersökning jämfört Bokmålsordboka, SO (2009) och Den Danske Ordbog (DDO). För det första har hon räknat antalet exempelmeningar med pronomen som hon/han, henne/honom och kommer då fram till att samtliga ordböcker har fler exempel med han. För det andra har hon granskat i vilken grad hon- och hanspråkprov uttrycker positiva eller negativa konnotationer, aktiva eller passiva subjekt och explicita könsstereotypa föreställningar. Undersökningen visar i korthet att det råder skillnader mellan verken, men att alla tre ordböcker skulle må bra av att revideras ur jämlikhetssynpunkt (se vidare nedan).

\section{[3] ORDBOKENS ROLL - ATT FÖRÄNDRA ELLER SPEGLA?}

En mycket viktig aspekt i detta sammanhang är vad ordboksförfattarna egentligen har för uppgift och vad ordboken ska åstadkomma. Å ena sidan kan man i korthet mena att förändringar av språket kan leda till förändringar av attityder i det omgivande samhället. Språkvårdande resurser som t.ex. ordböcker kan här spela en viktig roll. Exempelvis frågar sig Kram (1998:170) om det inte är en ordboksförfattares uppgift att i sina ordval stödja demokratiska processer. Hon ifrågasätter var gränsen går mellan att föra en tradition vidare och att problematisera sådana attityder som inte längre är önskvärda i det samhälle där ordboken ska fungera (se vidare bl.a. Wojahn 2015 om språkaktivism; se även t.ex. Fjeld 2015:54; Josephson 2018:205-206).

Ordboksförfattarna kan å andra sidan ta fasta på den typ av ordbok som de har fått i uppdrag att utarbeta eftersom detta har stora konsekvenser för ordbokens innehåll. Syftet med ordboken kan vara deskriptivt, dvs. att visa på hur språkbruket se ut. I enlighet med Moon (2014) finns det, utöver rent biologiska skillnader mellan kvinnor och män, skillnader i kvinnors och mäns livsföring. Detta reflekteras i ordförrådet, i attityder som kommuniceras via språket - och i ordböckernas innehåll. Ett exempel på en i första hand deskriptiv ordbok är således SO (2009). Men syftet med en ordbok kan också vara normativt, dvs. att styra språkbruket (Svensén 2009:24). SAOL är ett exempel på en sådan ordbok. Enligt Hageberg går det t.ex. inte att låtsas som att nedsättande beteckningar inte existerar, men hon är osäker på hur de bäst ska behandlas i ordböcker. Som möjliga alternativa lösningar anförs bl.a. utelämning av dylika ord i vissa verk, nyttjande av brukskommentarer och bruk av upplysningar till exempelvis inlärare, så att de kan undvika att använda den aktuella typen av ord (se även Whitcut 1983:141). Det råder dock flytande gränser mellan deskriptiva och normativa 
ordböcker och, som Svensén (2009:24) påpekar, uppfattas även deskriptiva ordböcker som normativa (se vidare avsnitt 7).

\section{[4] RÖSTER OM SO (2009):S INNEHÅLL}

I samband med uppdateringen av den lexikaliska databasen inför SO (2009) reviderades ordboksinnehållet ur könsperspektiv. Detta framgår exempelvis av Malmgren (2009:19) som påpekar att antalet hon i SO:s språkprov numera är ungefär lika stort som antalet han (jfr Fjeld 2015 ovan). Ett stort arbete som genomfördes inför 2009 var också att lägga till språkprov till de flera tusen idiom som ingår i ordboken. Även i samband med detta arbete strävade SO-redaktionen efter att uppnå ett jämställt innehåll och att idiomexemplen inte skulle visa upp en stereotyp och förlegad syn på könsroller (Hult 2012:216).

Det arbete som genomfördes uppmärksammas också av Nikula som i sin recension av SO (2009) menar att redaktionen nått en bit på väg. Hon skriver:

Ur genussynvinkel kan konstateras att en del av den gamla surdegen rensats bort bland exemplen. Både i SOB och i NEO fanns det gott om exempel där kvinnan sågs som beroende av mannen om hon över huvud tilläts visa sig (...) men numera är kvinna och man mer jämspelta (...). (Nikula 2010:364)

Denna förbättring påverkar, enligt Nikula, i och för sig inte ordbokens användbarhet i någon större utsträckning, men nu bidrar inte ordboken på samma sätt till spridning av stereotypa uppfattningar om könen.

Även Fjeld (2015:49) noterar att den bild som ges av kvinnor i SO är annorlunda än den bild som ges av kvinnor i exempelvis Bokmålsordboka (2005). Bl.a. innehåller SO en stor andel språkprov med ett aktivt hon. Det finns emellertid, enligt författaren, (2015:54) fortfarande tydliga spår av könsstereotypa gestaltningar i ordboken.

Det är enkelt att finna språkprov i SO (2009) som, gärna tillsammans med andra exempel med liknande innehåll, kan ifrågasättas. För det första finns exempelvis (under uppslagsorden revir och sluka) språkproven köket var hennes revir och han praktiskt taget slukade henne med blicken. För det andra finns det (under håhå och kräk) exempel som håhå, vad är det för en karl som inte kan laga bilen och han är ett beskedligt kräk som aldrig vågar säga emot sin fru. Exempel som dessa tyder på att SO-exemplen med kvinnor rör traditionella kvinnosysslor, att kvinnor objektifieras i ordboken, och att ordboken ger tydliga signaler om hur man ska uppträda för att betraktas som en riktig karl.

Exemplen under revir och sluka har för övrigt lyfts fram i en radiodebatt mel- 
lan litteratur- och genusforskaren Ebba Witt-Brattström och Sven-Göran Malmgren (Sveriges Radio 2016). I debatten förfäktade Witt-Brattstöm åsikten att SO befäster könsförtryckande strukturer och reproducerar stereotypa könsroller. Malmgren åberopade det genustänk som genomsyrat arbetet vid redaktionen inför SO (2009). Vidare påpekade han att det bl.a. finns en rad SO-exempel där också män är aktiva i köket. Malmgren konstaterade avslutningsvis att "man får nog komma med lite mer än en handfull anekdotiska exempel" för att visa på att ordboken reproducerar stereotypa könsroller. (Aftonbladet 22 dec. 2016).

[5] TJEJER OCH KILLAR I SO (2009) - RESULTAT AV EN FRITEXTSÖKNING

Mer systematiska undersökningar av hur flera, semantiskt relaterade ord som dam, herre, kvinna, man, gubbe, gymma, flicka, pojke, drottning och kung presenteras i SO (2009) kan utgöra stora och tidskrävande uppgifter. Detta gäller i synnerhet om man inte bara studerar aktuella uppslagsord utan också granskar hur de aktuella orden används i andra ordboksartiklar. Se t.ex. Kram som jämför artiklarna kvinna och man i en av föregångarna till SO (2009). Se också Agebjörn (2016) som studerar hur huvudbetydelserna hos bl.a. kvinna, man, tant, farbror, gumma och gubbe återges i So, hur motsvarande ord används i textmaterial som ingår i Språkbanken m.m.

Inom ramen för denna artikel har jag valt att granska samtliga träffar av olika böjningsformer av substantiven tjej respektive kille i SO (2009):s språkexempel till enskilda huvud- och underbetydelser. Att ta fram detta material är inte svårt; det kan vem som helst göra via en fritextsökning i appversionerna av SO.

Sammanlagt finns det 31 språkprov som innehåller tjej och 30 språkprov som innehåller kille (se tabell $1 \mathrm{i}$ bilagan till denna text). I vissa fall är det betydelserna 'flicka' resp. 'pojke' som är aktuella, andra gånger är det betydelserna 'flickvän' resp. 'pojkvän' som gäller.

En genomgång av materialet visar att en hel del SO-exempel kan betraktas som relativt sakliga. I någon mån speglar de också dagens verklighet (jfr Ohlander i avsnitt 2 ovan). Det gäller t.ex. det är ofta svårt att rekrytera tjejer till de tekniska programmen respektive sångerskan ackompanjerades av tre killar på gitarr, synt och percussion. Det kan dock vara samhälleliga förändringar på gång beträffande dessa förhållanden vilka redaktörerna givetvis måste vara uppmärksamma på.

Bland exemplen finns det tjejer och killar som är såväl aktiva som passiva. I ett fall som han tafsade på en tjej i krogkön och fick en spark i skrevet tillbaka är det både killen och tjejen som tar initiativ och agerar - även om handlingarna är av olika slag. Vidare beskrivs både tjejer och killar i positiva respektive negativa ordalag (jfr t.ex. det mer tilltalande en salt tjej med det mer nedlåtande en mesig liten kille). Om beskrivningen hans tjej var alltid villig ska betraktas som positiv 
eller negativ lämnas till läsaren av denna text att avgöra.

Av materialet framgår att både tjej- och kille-språkprov innehåller beskrivningar av utseende. Detta är dock vanligare i fall som inkluderar ordet tjej. Några exempel ur ordboken är han hade fätt korn på en snygg tjej, en ärtig tjej, en sportig tjej med hästsvans och keps, de nakna tjejerna på herrtidningens mittuppslag, en herrtidning med bilder på tjejer med nakna bröst och tjejerna hade tajta jeans. Killars utseende beskrivs främst genom adjektivet snygg: en snygg kille, hennes nye kille är en riktig snygging, hon hade en dejt med den snyggaste killen $i$ klassen.

Bland tjej-exemplen finns det också ett flertal språkprov som lyfter fram personliga egenskaper och karaktärsdrag (t.ex. en salt tjej, en skarp tjej, en tjej på sexton vårar, en torr tjej som aldrig ville gå på diskotek samt redan nämnda hans tjej var alltid villig). Vissa tjejer tycks vara ganska alldagliga (som i askungesagan om en vanlig tjej som gifte sig med en miljardär) och andra tycks vara bestämda och viljestarka (tjejerna har tuffat till sig och vågar säga sin mening). Det är emellertid betydligt vanligare att karaktärsdrag lyfts fram i kille-exemplen (se exempelvis en kul kille, en trevlig och lättsam kille, en städad kille, en mesig liten kille, en praktisk kille som renoverade huset själv, en teknisk kille som alltid lagar bilen själv, han är en reko kille, han verkar vara en hygglo kille samt den killen är helt nollställd). Exemplen ger som synes prov på flera manliga stereotypier, bl.a. den om den händige mannen, "hemmafixaren". I flera språkprov målas det även upp en bild av killar som mer aggressiva, våldsbenägna etc. (se t.ex. killari tonåren är ofta utagerande och aggressiva, killarnas snack var späckat med svordomar och han spöade upp killen som muckade gräl med honom på puben).

Bland såväl tjej-exemplen som kille-exemplen kan man se att framställningen av tjejer och killar utgår ifrån det motsatta könets perspektiv. I fall som bl.a. dessa betraktas tjejer eller händelser som rör tjejer ur ett mansperspektiv: hans flickvän gjorde slut och nu dejtar han en annan tjej, han råkade sätta sin tjej påjäsning, han pejlade in varenda tjej i lokalen, hans nya tjej, hans tjej är så skön, han började genast stöta på den snyggaste tjejen, killarna skulle gå på diskotek och ragga brudar. I fall som dessa återges istället män ur ett kvinnoperspektiv: hon hade en dejt med den snyggaste killen $i$ klassen, hon föredrog intellektuella killar, hon ska träffa sin kille ikväll, hon slog upp när hon träffade en annan kille och hon strular med två killar. Rent frekvensmässigt är det klart vanligare att tjejer i materialet återges ut ett manligt perspektiv än tvärtom.

Avslutningsvis finns det språkprov som är obegripliga ur alla perspektiv. Som redan framgått kopplar Nikula (2015) SO:s språkprov till ordbokens grad av användarbarhet. Språkprovet en kille och två tjejer bildade kvällens första triangel, som ska stödja en bildlig, erotisk innebörd av uppslagsordet triangel, stöder knappast 
betydelsebeskrivningen. Snarare fungerar det som distraktor för ordboksanvändaren och bör därför ersättas av något annat.

Sammanfattningsvis rymmer SO (2009) tjej- och kille-språkprov av mycket olika slag, Genomgången av materialet visar emellertid att tjej-exemplen innehåller fler beskrivningar av utseende, inklusive drag av objektifiering. Kille-exemplen handlar mer om karaktärsdrag. Många situationer som gäller tjejer beskrivs ur ett manligt perspektiv. Det är heller inte ovanligt med schabloner kring hur män tänker och uppträder och indikationer om hur en "riktig" karl ska vara (jfr Nikulas 1997 diskussion kring dold och mer försåtlig diskriminering eller smygsexism i avsnitt 2 ovan). Av min undersökning framgår det således att SO (2009) kan sägas upprätthålla eller kanske t.o.m. befästa stereotypa tankegångar om hur kvinnor - men också män - förväntas vara, ha för kunskaper o.s.v. (jfr Kram 1998:159-160; Ishikawa 2013).

Vad finns det då för stöd för denna återgivning av de två substantiven i korpusar med svenskt samtida språk? Om SO:s primära uppgift är att beskriva språkbruket och unga kvinnor och män beskrivs på olika sätt och förekommer i olika sammanhang i textmaterialen, kanske detta ordboksinnehåll är fullt rimligt. För att få klarhet i hur språkbruket faktiskt ser ut har jag med konkordansverktyget Korp gjort en sökning på lemgrammen tjej respektive kille i en delmängd av Språkbankens korpusar. De aktuella korpusarna består av moderna texter av olika slag (tidningstexter, romaner, akademiska texter och bloggtexter) och antalet löpande ord i delmängden är drygt 2 miljarder. Med tanke på alla de texter som finns att tillgå i Språkbanken och de stora korpusar som man numera nyttjar inom lexikografiskt arbete måste delmängden betraktas som relativt begränsad. Ett skäl till avgränsningen är att många typer av sökningar i Korp tyvärr är mycket tidsödande - ur lexikografens perspektiv tar det orimligt lång tid att få fram ett resultat av sin sökning.

Totala antalet förekomster av böjningsformer av tjej och kille är 354135 respektive 292392 i det aktuella textmaterialet. Med tanke på det stora antalet träffar är det för lexikografen närmast omöjligt att titta på hur ordet används i KWIK-konkordanser. Däremot är Korps ordbildsvisning mycket användbar (se vidare Borin et al. 2012). Tack vare ordbilden kan man med lätthet överblicka det syntaktiska sammanhang som ett ord förekommer i. Av ordbilden framgår också ordets typiska subjekt, objekt och adverbial (jfr motsvarande resurser i anslutning till Leksikografisk bokmålskorpus och KorpusDK; se vidare bl.a. Fjeld \& Henriksen 2012 och Trap-Jensen 2009 om dessa korpusar). En genomgång av sökresultaten i de svenska korpusarna visar bl.a. att det i hög grad är samma attribut som återkommer bland 10-i-topp-orden i de bägge ordbilderna. Såväl tjejer som killar beskrivs med ord som ung, liten, duktig, snygg, glad och fin. Det är 
dock vanligare att bruket av ordet tjej sammanfaller med adjektivet söt. På samma sätt är det vanligare att kille sammanfaller med adjektivet snäll. Resultat som dessa behöver beaktas vid revidering av ett svenskt ordboksunderlag.

Utifrån det ovan sagda, borde ett flertal exempel i So (2009) modifieras eller helt bytas ut i samband revideringen av databasen. För att verkligen kunna ta ställning till enskilda språkexempel som dessa måste ordboksredaktören emellertid kontrollera språkbruket i olika moderna korpusar, studera i vilka sammanhang exemplen förekommer, huruvida de betydelser som orden ska illustrera är försedda med brukskommentarer etc. Om det via en kommentar framgår att en viss användning är nedsättande påverkar det givetvis bedömningen av det aktuella språkprovet.

\section{[6] ANVÄNDARSYNPUNKTER PÅ SO (2009):S INNEHÅLL}

Numera är det inte ovanligt att ordboksinnehåll uppmärksammas och debatteras i olika sammanhang på internet. Som exempel kan den diskussion som rått kring språkexemplet rabid feminist under uppslagsordet feminism i Oxford Dictionary of English nämnas (se vidare t.ex. Bolt 2016, Flood 2016 och 2020; se även twitterinläggen under t.ex. \#dictionarygate).

Visst innehåll i SO (2009) har också fått stor uppmärksamhet bland ordboksanvändare. Först och främst är det ordboksartikeln mesig som stått i fokus. Ordet, med huvudbetydelsen 'rädd och ynklig', har två underbetydelser och den ena av dessa åtföljs av ett, enligt nuvarande redaktion, mycket olyckligt språkprov, mesig tjejfotboll. I korthet tycks nyheten om ordboksinnehållet ha spridit sig genom att en privatperson uppmärksammade Svenska Fotbollförbundet (SvFF) på att damfotboll nämndes i ett mindre smickrande sammanhang i SO. SvFF publicerade ett inlägg på damlandslagets officiella Instagram-konto med en bild på ordboksartikeln åtföljt av frågan "Har vi inte kommit längre än så här Svenska Akademien?" (Fagerlund 2018). Inlägget spreds sedan snabbt vidare. Språkprovet uppmärksammades också av flera svenska tidningar och snart hade SO-redaktionen mottagit ett förhållandevis stort antal e-brev, inklusive ett från SvFF. En del mejl var sakligt formulerade, andra mer aggressiva och nedlåtande till sin natur. I ännu några mejl uttrycktes sorg över sakernas tillstånd (se utdrag ur några brev i nedan).

Hur kan detta hända 2018? Vilka signaler tror ni att det ger?! Gör om, gör rätt! (Av Camilla H.)

Det räckte inte med att vi damspelare får de sämsta omklädningsrummen, de sämsta träningstiderna på de mest sönderspelade leriga planerna ... samt en massa skit bland media och allmän opinion - ni 
kände att ni ville trycka till oss lite grammatiskt också? :) (Av Jenny W.)

Om jag söker på ordet mesig så får jag upp "mesig tjejfotboll" som förslag ..., varför inte byta ut mot "Mesig ledamot av "fina" Svenska Akademien" istället? Har vi inte kommit längre 2018? Sorgligt att NI av alla uttrycker er så, pinsamt. Klipp er och skaffa er ett nytt jobb, jag tar gärna ert arbete och lön så kommer det bli ordning och reda. (Av Olle G.)

... För mig som mamma till två fotbollsspelande tjejer så är de allt annat än mesiga. Pinsamt är det!!! Hoppas på snar ändring!! (Av Ulrika F.)

Mycket av materialet i SO (2009) härstammar från föregångarna SOB och NEO och en hel del exempel är därmed från 1980-talet och av naturliga skäl i behov av modernisering. Så är emellertid inte fallet med detta språkprov: det lades in $\mathrm{i}$ databasen inför SO (2009). Eventuellt hade redaktionen kunnat åberopa att mesig tjejfotboll är en återkommande ordkombination och att den därför försvarar sin plats i en ordbok som ska återge hur modernt språkbruk ser ut, men så är det heller inte. En sökning i Korp visar att ordkombinationen, då språkprovet uppmärksammades, inte förekom en enda gång i de då allmänt tillgängliga korpusarna på mer än 13 miljarder löpande ord.

Så, för att sammanfatta, samtidigt som ett stort antal språkexempel uppdaterades och reviderades ur genussynpunkt inför SO (2009), inarbetades det olämpliga exempel i databasen. Det enda redaktionen nu kunde göra i fallet mesig tjejfotboll var att svara skribenterna att modernisering av ordboksdatabasen pågår och att So har till uppgift att spegla det faktiska språkbruket men däremot inte att ge rekommendationer om hur orden ska användas (jfr avsnitt 3 ovan). Det betonades också att redaktionen inte står bakom alla de åsikter eller värderingar som kan komma till uttryck i de exempel som ges. I svaret meddelades också att exemplet var borttaget ur databasen. I och med att SO i svenska.se inte uppdateras löpande är detta emellertid inte synligt för användarna ännu.

Redaktionens svar till SvFF och användarna spred sig snabbt och snart kunde man läsa mer positiva rubriker i bl.a. pressen. Se t.ex. utdraget ur Dagens Nyheter i figur 1. 


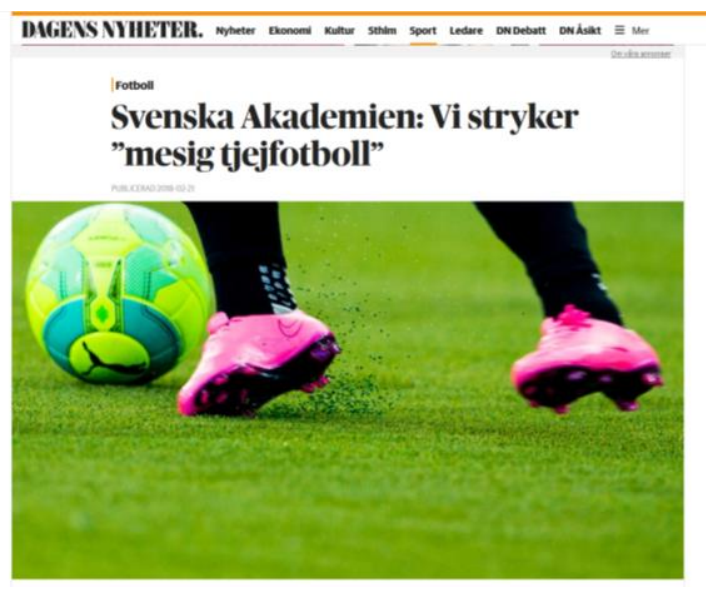

FIGUR 1. Del av nyhetsartikel, publicerad i Dagens Nyheter 21 febr. 2018

Just detta exempel illustrerar det faktum att ordböckers innehåll kan granskas och spridas på ett annat sätt än tidigare. Det visar på att även ordböcker och ordboksarbete lyder under den nya mediala logik som tillkomsten av internet och sociala medier har gett upphov till. Är det något $\mathrm{i}$ ordboken som inte tillfredsställer användarna hör de av sig på ett annat sätt än förut. Redaktionen är bara en knapptryckning bort och detta har både positiva och negativa sidor. Lexikograferna tar emot synpunkter och kommentarer av olika slag och vissa av dem kan leda till förbättringar av databasen - om det finns stöd för dessa ändringar i de språkliga material som används i samband med det lexikografiska arbetet.

[7] DET PÅ ÅNDE OCH FRAMTIDA ARBETET MED SO

\section{- UR KÖNSPERSPEKTIV}

Hittills har upplagan från 2009 uppmärksammats. Hur ser det då ut inför nästa upplaga av SO? Det arbete som lades på att utveckla innehållet ur ett genusperspektiv i den första utgåvan har fortgått med sikte på kommande upplaga av ordboken. Det är ett stort arbete som bl.a. innebär att många språkprov revideras eller helt enkelt stryks. Som redan framgått baserades första upplagan av SO (samt föregångarna SOB 1986 och NEO 1995-1996), i första hand på etablerat, redigerat skriftspråk i tidningar och romanmaterial. Sedan arbetet med den första upplagan av SO pågick har tillgången till textmaterial ökat i det närmaste lavinartat och exempelvis Språkbanken innehåller nu betydligt fler delkorpusar av olika slag än tidigare. Inte minst är vardagligt, talspråksnära språk nu tillgängligt på ett helt annat sätt än tidigare och det måste lexikografin förhålla sig till. Det är svårt att hävda att inte texter publicerade på åtminstone vissa sociala 
medier ska in i underlaget för den nya upplagan (se vidare Sköldberg \& Hannesdóttir 2017).

Som tidigare konstaterats finns det inte, med tanke på Korp, stöd för att lägga in en ordkombination som mesig tjejfotboll i databasen. Däremot kan det finnas fog för att lägga in eller bevara andra uppslagsord, betydelsebeskrivningar och ordkombinationer - hur provocerande och sexistiska de än må vara. Som exempel är det, i modern svenska, framför allt kvinnoben som är välsvarvade. Vidare är det främst kvinnor som framställs som neurotiska och på det sexuella området är det framför allt kvinnor som betecknas som lättfotade. Söker man på vissa uppslagsord är det alltså lätt att få intryck av att kvinnor och kvinnors kroppar objektifieras. Kvinnor kan också sägas tilldelas mindre tilltalande psykiska egenskaper. Dessutom skambeläggs kvinnlig sexualitet (se t.ex. Caldas-Coulthard \& Moon 2010 om asymmetrier i hur kvinnor och män presenteras med hjälp av bl.a. adjektivattribut i engelsk press. Se även Fjeld \& Knudsen 2013 om könsdiskriminering i norska texter som ingår i Leksikografisk bokmålskorpus). I detta sammanhang är det alltså inte lemmaansättningen som utgör problemet (jfr Nikula 2008a ovan), men aktuella ord måste beskrivas på ett lämpligt sätt. De måste exempelvis förses med uppgifter som informerar användarna sin negativa laddning m.m.

Balansgången mellan att stryka illa valda exempel, att ducka för reellt språkbruk och att bli för politisk korrekt inom ramen för det lexikografiska arbetet är svår (jfr Ohlander om val av okontroversiella ämnen i grammatikexemplen ovan). Korpusinnehållet, och de resultat som man får av korpussökningar, måste också diskuteras. Som exempel kan det svenska adjektivet rabiat anföras (jfr engelskans rabid och språkprovet rabid feminist i avsnitt 6 ovan). Enligt SO (2009) betyder ordet rabiat 'okontrollerat ursinnig' men det kan också användas rent förstärkande. Som exempel på denna underbetydelse anförs språkprovet en rabiat nationalist. Huruvida detta är en lyckad ordkombination kan diskuteras. Svaret beror nog på hur man ser på innebörden i ordet nationalist och om man anser att det har en positiv eller negativ klang. En ordbild av ordet, baserad på samma Korp-delmängd som användes i samband med undersökningen av orden tjej och kille i avsnitt 5 , visar följande 15 ord som attribut till de 1878 beläggen på ordet.

feminist, manshatare, motståndare, flatfeministen, kärring, folklighetskult, menskossor, ateist, antisemit, flat-feministen, köttätare, eu-motståndarna, nationalist, eu-motståndare, rasist

Många av substantiven i listan har som synes påtagligt negativ klang. Eventuellt kan man tro att det är korpustexterna från sociala medier som får genomslag i 
detta sammanhang och att ordbilden skulle se annorlunda ut om man endast använde redigerade texter med mer vårdat språk. En sökning i samma delmängd korpusar, men där endast texter hämtade från tidningar och skönlitteratur ingår, ger emellertid följande, $i$ långa stycken liknande, ordbild:

feminist, folklighetskult, antisemit, motståndare, feministdjävlar, manshatare, klimatalarmist, antisemitism, eu-motståndare, nedskärning, inställning, kritiker, nationalist, kritik, manskvinnor

Om redaktionen strikt rättade sig efter innehållet i olika texter i Språkbanken skulle således rabiat feminist kunna läggas in i databasen som språkprov. Detsamma gäller ordkombinationer som rabiat flatfeminist, rabiat kärring etc. och frågan är hur lyckat det är. En beskrivning av SO:s uppdrag, att spegla faktiskt språkbruk, återfinns i och för sig i ordbokens inledning, men denna beskrivning tar de flesta inte del av. Här kan man därför tänka sig att en lämplig lösning kan bestå i att det nuvarande exemplet en rabiat nationalist ersätts av det mer neutrala en rabiat motståndare. Också denna ordkombination är förhållandevis vanlig i textmaterialen (se ovan) och exemplet torde inte utgöra en distraktor för den betydelse som det ska illustrera.

I ett fall som rabiat krävs det nästan att ordboksartikeln innehåller språkexempel med rabiat + substantiv för att typiskt bruk av ordet ska illustreras. Det är dock inte alltid så. Som exempel kan ett annat adjektiv, känslig, anföras. Ett sätt att göra framtida ordboksartiklarna i SO mer könsneutrala är, i enlighet med Whitcut (1983:143), att man byter ut pronomen som han till hon, han till de etc. i språkproven. Denna typ av utbyten skedde i samband med arbetet inför SO (2009). Ett annat sätt är att använda sig av fler s.k. "döda" språkprov (Svensén 2009:147). Kännetecknande för dessa är att nominalfraser ofta har neutraliserats till indefinita pronomen och verbens finita former till infinitiver. I artikeln känslig i SO (2009) finns det flera språkprov, bl.a. hon har en känslig mage; du fär inte ryta åt henne, hon är så känslig samt han är känslig för kritik. Dessa språkprov ska således stödja betydelsebeskrivningen och ge info om uppslagsordets fraseologi. I just detta fall framställs såväl kvinnan som mannen som svaga i något avseende och man kan tycka att de negativa exemplen i ordboksartikeln i viss mån "tar ut varandra". För att uppnå högre grad av könsneutral språkbeskrivning, men ändå bibehålla information om vilka ord adjektivet ifråga tenderar att uppträda med, kan emellertid två av språkproven kortas (jfr ha känslig mage och vara känslig för kritik). Ett exempel som du får inte ryta åt henne, hon är så känslig bör man dock överväga om man inte ska stryka eftersom betydelsen hos ordet känslig stöds av andra språkprov och det inte illustrerar någon återkommande ordkombination (jfr resonemangen kring distraherande exempel ovan). 
[8] SAmtLiga Diskrimineringsgrunder MÅste BEAKTAS Vid ORDBOKSARBETE

Genusperspektivet är viktigt, men fler perspektiv måste anläggas vid lexikografiskt arbete och ett normkritiskt perspektiv måste hela tiden vara aktuellt. Det behövs också fler normkritiska studier av hur det ser ut i dagens ordböcker. I nuläget är dessa studier begränsade till sitt antal (se dock Moons 2014 övergripande artikel med anförda referenser om ideologiskt laddade ord i engelska inlärningsordböcker. Se även t.ex. Nikula $2008 \mathrm{~b}$ om åldersstereotypier i olika svenska ordböcker). Lexikografer behöver granska sina material utifrån samtliga diskrimineringsgrunder (dvs. kön, könsöverskridande identitet eller uttryck, etnisk tillhörighet, religion eller annan trosuppfattning, funktionsnedsättning, sexuell läggning, ålder) (se https://www.do.se/om-diskriminering/vad-ar-diskriminering/). Exempel på ord som kan relateras till svenska diskrimineringsgrunder är redan nämnda tjej och kille men också brud, bitch, hora, icke-binär, cisperson, blatte, blekansikte, hedersvåld, adhd, funkofobi, funktionsvariation, miffo, vanför, bög, flata, fjolla, tant, gubbe och ålderism. Några av dessa ord är äldre och upptas redan i många ordböcker medan andra är nyare och kanske inte fullt så etablerade i språket. Ord som dessa studerades förstås extra redan inför i SO (2009) men de behöver återigen granskas ur ett normkritiskt perspektiv.

Redaktörerna måste också, i enlighet med t.ex. Moon (2014), vara uppmärksamma på hur olika samhällsgrupper framställs inne i ordboksartiklarna. Som exempel kan frågan om hur äldre personer skildras nämnas (se t.ex. Moon 2014:86-87 om den negativa bild som ges av äldre i engelska ordböcker under det till synes oladdade ordet cardigan). Kritiska genomgångar av ordboksmaterial bör således inkludera studier av vilka uppslagsord som är med (inkl. vilka som saknas). De behöver också gälla vilka ord som används i beskrivningarna och innehållet i de språkprov som anförs. De måste också avse bruk av brukskommentarer av slaget <nedsättande>, <kan uppfattas som stötande> och <mest historiskt> vilka informerar användarna om uppslagsordens stilnivå, värdeladdning m.m. (jfr Hageberg i avsnitt 2 ovan).

För att ytterligare förtydliga ovan nämnda tankegångar i förhållande till innehållet i nästa upplaga av SO kan också substantivet ras nämnas. Detta ord har kommit att ifrågasättas i vetenskapliga sammanhang. Idén om människoraser är inte förenlig med modern, samtida vetenskap och av detta skäl har SO-redaktionen kommit fram till att antalet användningar av ordet bör begränsas så långt det bara går i nästa upplaga av ordboken. Samtidigt kan det inte helt tas bort. Ordet som sådant samt en rad sammansättningar med ras används fortfarande i modernt språk, t.ex. rasbiologi, rasdiskriminering, rashets och rasmotsättning. Dessa 
får därmed vara kvar i So, antingen som egna uppslagsord eller som morfologiska språkprov i andra artiklar. Vid behov behöver de dock förses med brukskommentarer av olika slag, t.ex. <ngt åld.>. Att helt bortse från dem och stryka dem ur ordboken vore dock att ge efter för politisk korrekthet i för stor grad (jfr Ohlander i avsnitt 2 ovan). I SO (2009) används ordet ras emellertid också inne i andra artiklar (se t.ex. eskimå och mörkhyad) och där kan det många gånger utelämnas eller ersättas av exempelvis etnisk tillhörighet.

Utöver diskrimineringsgrunderna behöver redaktörerna också granska andra kontroversiella teman som kroppsform, klass, politisk ståndpunkt, stad vs. landsbygd och sexualitet. Exempelvis kan det diskuteras hur övervikt och fetma framställs i ordböcker. En genomgång av SO (2009) visar t.ex. att till uppslagsord som trakassera, hånfull och håna hör språkprov som den tjocka pojken trakasserades av kamraterna, den fete mannen omgavs av en hånfull skara barn och barnen hånade honom för hans fetma. Betydelsen hos ett ord som stilig illustreras istället av ett exempel som hon var en stilig kvinna, slank och rakryggad. Frågan är vad språkprov som dessa ger för signaler. Kan man säga att de helt enkelt ligger i linje med den syn på övervikt som är förhärskade i samhället av idag? Eller reproducerar och förstärker de denna syn?

En för lexikografen komplicerande omständighet är att antalet ord i ordboksdatabaser är mycket stort, och att bruket av ett visst ord snabbt kan förändras över tid. Vissa laddade ord kan desutom återtas, reclaimas, (se Edlund et al. 2007:209-210 och Wojahn 2015:129-130 om laddningen hos beteckningar som bög och flata). Alternativa ord som funkofobi och funktionsvariation lanseras men det är inte säker att de etableras. Om de får större spridning är det inte självklart vilken eller vilka betydelser de då får och vilken laddning de har bland olika användargrupper.

\section{[9] SLUTORD}

Ordböcker har anklagats för att ge en skev bild av kvinnor och män, kvinnligt och manligt. Dels har det riktats kritik mot att det ordförråd som är förknippat med kvinnor och kvinnors liv, såsom beteckningar på traditionella kvinnosysslor, inte är lika representerat i ordböckerna som motsvarande manliga ordförråd. Dels har det riktats kritik mot hur personer tillhörande det kvinnliga könet framställs överlag.

Den databas som ligger till grund för SO, dvs. Svensk ordbok utgiven av Svenska Akademien, har väldigt många förtjänster men betydande delar av innehållet $\mathrm{i}$ databasen är från 1980-talet och behöver revideras. En hel del har förändrats sedan SO (2009) utarbetades (se vidare Sköldberg \& Hannesdóttir 2017). Detta 
gäller inte minst det omgivande samhället, men det gäller också förutsättningarna för ordboksarbete, tillgången till korpusar och avståndet mellan ordboksredaktörerna och ordboksanvändarna.

Redaktionen för SO behöver arbeta vidare med den granskning och revidering ur genussynpunkt som skedde i databasen inför den första upplagan av verket. En nyanserad och varierad bild av både kvinnor och män, flickor och pojkar måste eftersträvas. Nikula (2008a:310) menar att vägen till en ordbok där könen är jämställda på alla nivåer tar sin början vid valet av uppslagsord. Olika ordförråd bör täckas in i en ordbok som gör anspråk på att beskriva svenskt samtida språkbruk. Men ordboksredaktörerna måste också se hur de aktuella uppslagsorden definieras, om kontroversiella ord används i definitioner, vad språkproven ger för signaler och om brukskommentarer används på ett adekvat och rättvisande sätt.

Behovet av kritiskt lexikografiska studier är stort. Genom mer systematiska granskningar kan den smygsexism som Nikula (1997) diskuterar uppenbaras. Nuvarande SO-redaktion består av såväl kvinnor som män i olika åldrar, men det utgör, som Hageberg (1990) konstaterar, ingen garanti för att alla könsstereotyper tvättas bort. Desto viktigare är att det råder medvetenhet inom redaktionen kring normkritiska frågeställningar så att exempelvis inte nya, mindre lyckade exempel av slaget mesig tjejfotboll läggs in i databasen under revideringsarbetets gång (jfr avsnitt 6 ovan).

Balansgången mellan att stryka eller modifiera illa valda exempel och att bli för politisk korrekt är svår. Whitcut (1983:143-144) konstaterar att lexikograferna kan gå för långt i sin iver att radera könsstereotyper och att exemplen därigenom blir helt onaturliga ur brukssynpunkt (jfr även Ohlander om val av okontroversiella ämnen i grammatikexemplen). En viktig förutsättning för att ordboksarbetet ska bli så bra som möjligt är tillgången till större, balanserade och språkligt sett varierade korpusar. Utöver detta behövs välfungerande korpusverktyg som snabbt kan hjälpa lexikograferna att se återkommande mönster i stora material. Är bruket tillräckligt starkt i den korpus som används kan detta stödja ordboksförfattarna att på ett så adekvat sätt som möjlig ge sig i kast med kontroversiella ord och ordförbindelser (jfr rabiat feminist). Utbudet av såväl korpusar som adekvata korpusverktyg torde dock variera inom bl.a. Norden. I Sverige finns det stora korpusar med varierat språkbruk i bl.a. Språkbanken, men tillgången till senare textmaterial och snabba verktyg är tyvärr inte tillfredsställande i dagsläget.

En hel del torde trots allt ha hänt i svenska ordböcker de senaste decennierna och man borde kunna skönja förändringar till de bättre (jfr t.ex. Nikula 2010 och Fjeld 2015 om gamla surdegar i föregångare till SO). Det vore dock intressant att, 
i analogi med Ohlander (1995) och Lewandowski (2014), anlägga ett historiskt perspektiv på svenska ordböcker och exempelvis se hur språkproven ser ut i Dalins enspråkiga ordbok från 1850-talet. Det kunde ge nyttiga perspektiv på dagens exempelmeningar.

Det räcker emellertid inte att anlägga ett genuskritiskt perspektiv under det lexikografiska arbetet. Alla diskrimineringsgrunder måste beaktas (dvs. kön, könsöverskridande identitet eller uttryck, etnisk tillhörighet, religion eller annan trosuppfattning, funktionsnedsättning, sexuell läggning, ålder). Ett normkritiskt perspektiv bör hela tiden vara aktuellt i samband med ordboksförfattandet. Lexikograferna behöver också vara uppmärksamma på hur andra kontroversiella ämnen, t.ex. de idéer som rör vår tids kroppsfixering, behandlas i de verk de arbetar med. Förhoppningsvis kan det leda till mer inkluderande ordböcker i framtiden.

\section{REFERENSER}

Aftonbladet 2016. Genuskritik mot Svensk ordbok. Publicerat: 22 december 2016. Tillgängligt via https://www.aftonbladet.se/nyheter/a/5K7gK/genuskritikmot-svensk-ordbok.

Arimbi, Diah, A. \& Deny A. Kwary. 2016. Linguistic Turn and Gendering Language in the Cambridge Advanced Learner's Dictionary. I English Language teaching $9,166-174$.

Bokmålsordboka 2005. 3. reviderte utgave. Oslo: Kunnskapsforlaget.

Bolt, Adam. 2016. Feminists attack Oxford Dictionary of English for 'reinforcing sexist stereotypes'. I The Telegraph 23 januari 2016. Tillgängligt via https://www.telegraph.co.uk/news/uknews/12117574/Feminists-attackOxford-Dictionary-of-English-for-reinforcing-sexist-stereotypes.html

Borin, Lars, Markus Forsberg \& Johan Roxendal. 2012. Korp - the corpus infrastructure of Språkbanken. I Proceedings of LREC 2012, 474-478. Istanbul: ELRA.

Caldas-Coulthard, Carmen \& Rosamund Moon. 2010. 'Curvy, hunky, kinky': Using corpora as tool for critical analysis. I Discourse \& Society 21(2), 99-133.

Edlund, Ann-Catrine, Eva Erson \& Karin Milles. 2007. Språk och kön. Stockholm: Norstedts.

Epple, Barbara. 2000. Sexismus in Wörterbüchern. I Ulrich Heid, Stefan Evert, Egbert Lehmann \& Christian Rohrer (red.), Proceedings of the 9th EURALEX International Congress, 739-754. Stuttgart. 
Fagerlund, Frida. 2018. Svenska Akademien: "Mesig tjejfotboll". Publicerat i Aftonbladet 19 febr. 2018. Tillgängligt via https://www.aftonbladet.se/sportbla$\operatorname{det} /$ fotboll/a/J1l3X8/svenska-akademien-mesig-tjejfotboll.

Fjeld, Ruth Vatvedt. 2001. Ingenting å snakke om - kvinneord og ordbøker. I Språknytt 4, 10-13.

Fjeld, Ruth Vatvedt. 2015. Om ordbokseksempel og stereotypisering av kjønn i noen nordiska ordbøker. I Caroline Sandström, Ilse Cantell, Eija-Riitta Grönros, Pirkko Nuolijärvi \& Eivor Sommardahl (red.), Perspektiv på lexikografi, grammatik och språkpolitik i Norden, 35-65. Helsingfors.

Fjeld, Ruth Vatvedt \& Petter Henriksen. 2012. The BRO-project, a bridge in the wild, Norwegian linguistic landscape. I Ruth Vatvedt Fjeld \& Julie Matilde Torjusen (red.), Proceedings of the 15th EURALEX International Congress, 936-946. Oslo: Institutt for lingvistiske og nordiske studier, Universitetet i Oslo.

Fjeld, Ruth Vatvedt \& Rune Lain Knudsen. 2013. Balance, Depth, Synergies - Assembling a Corpus for Documenting Ideal and Reality in Lexis. I Deny A. Kwary et al. (red.), Lexicography and Dictionaries in the Information Age. Selected papers form the 8th ASIALEX International Conference, 360-361. Surabaya: Airlangga University Press.

Flood, Alison. 2016. Sexism row prompts Oxford Dictionaries to review language used in definitions. I The Guardian, 25 januari 2016. Tillgängligt via https://www.theguardian.com/books/2016/jan/25/oxford-dictionary-review-sexist-language-rabid-feminist-gender.

Flood, Alison. 2020. No more 'nagging wives': how Oxford Dictionaries is cleaning up sexist language. I The Guardian, 6 mars 2020. Tillgängligt via https://www.theguardian.com/books/2020/mar/06/no-more-nagging-wives-how-oxford-dictionaries-is-cleaning-up-sexist-language.

Josephson, Olle. 2018. Språkpolitik. Stockholm: Morfem.

Hageberg, Arnbjørg. 1990. Kvinner og men og ordbøker. Norsk Lingvistisk Tidsskrift 8, 48-67.

Hult, Ann-Kristin. 2010. Kort och gott. Om idiomens språkprov i Svensk ordbok utgiven av Svenska Akademien (2009). I Kristina Nikula \& Harry Lönnroth (red.), Nordiska Studier i Lexikografi 10, 209-222. Tammerfors.

Ishikawa, Yuka. 2013. Gender stereotypes seen in dictionary descriptions published in Japan. I Deny A. Kwary et al. (red.), Lexicography and Dictionaries in 
the Information Age. Selected papers form the 8th ASIALEX International Conference, 222-227. Surabaya: Airlangga University Press.

Korp, Språkbankens konkordansverktyg. https://spraakbanken.gu.se/korp/, hämtat augusti 2019.

KorpusDK. https://ordnet.dk/korpusdk, hämtat augusti 2019.

Kram, Kristina. 1998. "... blott rent undantagsvis om kvinnor." Om representation av kvinnan i moderna ordböcker. I Språk och stil 8, 159-171.

Landau, Sidney I. 2001. Dictionaries. The art and craft of lexicography. (Second edition). Cambridge: Cambridge University Press.

Leksikografisk bokmålskorpus. https://www.hf.uio.no/iln/tjenester/kunnskap/sprak/korpus/skriftsprakskorpus/lbk/, hämtat augusti 2019.

Lewandowski, Marcin. 2014. Gender stereotyping in EFL grammar textbooks. A diachronic approach. I Linguistik online 68, 83-99. Tillgänglig via https://bop.unibe.ch/linguistik-online/article/view/1635/2763.

Malmgren, Sven-Göran. 2009. LEDA-Nyt 47, 14-20.

Mattisson, Anki. 2006. Genusperspektiv på SAOB:s källor. I LexicoNordica 13, 5568.

Moon, Rosamund. 2014. Meanings, Ideologies, and Learners' Dictionaries. I Andrea Abel, Chiara Vettori \& and Natascia Ralli (red.), Proceedings of the 16th EURALEX International Congress, 85-105. Bolzano.

NEO = Nationalencyklopedins ordbok 1995-1996. Band 1-3. Höganäs: Bra böcker.

Nikula, Kristina. 1997. Språkprov i könsperspektiv. I Rune Ingo, et al. (red.), Fackspråk och översättningsteori. VAKKI-symposium XVII, 194-206. Vasa: Vasa universitet.

Nikula Kristina. 2008a. Kvinnligt och manligt. Illustrationerna i Bonniers svensk ordbok I Kristinn Jóhannesson et al. (red.), Nog ordat? Festskrift till Sven-Göran Malmgren den 25 april 2008, 304-311. Göteborg.

Nikula Kristina. 2008b. Pensionär - aldrig i livet. De äldre i ordböckerna. I Ásta Svavarsdóttir et al. (red.), Nordiske studier i leksikografi 9, 337-351. Reykjavík.

Nikula, Kristina. 2010. Svensk ordbok - en guldgruva för språkintresserade. I LexicoNordica 17, 351-375. 
Ohlander, Sölve. 1995. "A wise Man Controls His Passions" - Of men and women, morals and mentality in four hundred years of English grammar examples. I Gunnel Melchers \& Beatrice Warren (red.), Studies in Anglistics, 217-236. Stockholm: Almqvist \& Wiksell.

Pilke, Nina. 2009. Hon arbetar som extrabiträde - han blev chef för avdelningen. Kvinnlig och manlig yrkesbild i ljuset av exempelmeningar i en tvåspråkig cd-romordbok. I Mona Enell-Nilsson \& Niina Nissilä (red.), Language and Power. VAKKI Symposium XXIX, 332-342. Vasa, Vasa universitet.

SAOB = Svenska Akademiens ordbok, 1898-. Tillgänglig via https://svenska.se/.

SAOL $=$ Svenska Akademiens ordlista, 2015. Fjortonde upplagan. Tillgänglig via https://svenska.se/.

Sköldberg, Emma \& Anna Helga Hannesdóttir. 2017. Svenska ord - men vilka? Om uppslagsorden i Svensk ordbok utgiven av Svenska Akademien. I Emma Sköldberg et al. (red.), Svenskans beskrivning 35. Göteborg: Göteborgs universitet, 329-340.

Språkbanken. https://spraakbanken.gu.se/, hämtat augusti 2019.

SO = Svensk ordbok utgiven av Svenska Akademien, 2009. Tillgänglig via https://svenska.se/.

SOB = Svensk ordbok 1986. Solna: Esselte studium.

Svensén, Bo. 2009. A handbook in lexicography. The theory and practice of dictionarymaking. Cambridge.

Sveriges Radio 2016. Svensk ordbok kritiseras för stereotypa könsroller. Sändes 22 december 2016. Tillgängligt via https://sverigesradio.se/sida/artikel.aspx?programid=83\&artikel=6591853 (augusti 2019).

Trap-Jensen, Lars. 2009. Access to multiple lexical resources at a stroke: integrating dictionary, corpus and Wordnet data. I Sylviane Granger \& Magali Paquot (red.), eLexicography in the 21st century. New challenges, new applications. Proceedings of eLex 2009, 295-305. Louvain-la-Neuve.

Whitcut, Janet. 1983. Sexism in dictionaries. I Reinhard R. K. Hartmann (red.), LEXeter '83. International Conference on Lexicography at Exeter. (Lexicographica. Series Maior 1.), 141-144. Berlin: De Gruyter.

Wojahn, Daniel. 2015. Språkaktivism. Diskussioner om feministiska språkförändringar 
i Sverige från 1960-talet till 2015. (Skrifter utgivna av institutionen för nordiska språk vid Uppsala universitet 92.) Uppsala.

BILAGA

Språkprov i SO 2009 som ska stödja huvudbetydelser och underbetydelser och som innehåller någon böjningsform av substantiven tjej eller kille. Aktuella uppslagsord indikeras med hjälp av fetstil.

\begin{tabular}{|c|c|}
\hline Tjej & Kille \\
\hline $\begin{array}{l}\text { askungesagan om en vanlig tjej som } \\
\text { gifte sig med en miljardär }\end{array}$ & $\begin{array}{l}\text { hon hade en dejt med den snyggaste kil- } \\
\text { len i klassen }\end{array}$ \\
\hline $\begin{array}{l}\text { en herrtidning med bilder på tjejer med } \\
\text { nakna bröst }\end{array}$ & hon föredrog intellektuella killer \\
\hline $\begin{array}{l}\text { hans flickvän gjorde slut och nu dejtar } \\
\text { han en annan tjej }\end{array}$ & han verkar vara en hygglo kille \\
\hline flukta på tjejer & hon ska träffa sin kille i kväll \\
\hline tjejer är bara förnamn på hans problem & tjejer och killer \\
\hline han råkade sätta sin tjej på jäsning & en kul kille \\
\hline en sportig tjej med hästsvans och keps & en trevlig och lättsam kille \\
\hline han kladdar på tjejerna när han dansar & en mesig liten kille \\
\hline han hade fått korn på en snygg tjej & den killen är helt nollställd \\
\hline en läskigt snygg tjej & $\begin{array}{l}\text { sångerskan ackompanjerades av tre kil- } \\
\text { lar på gitarr, synt och percussion }\end{array}$ \\
\hline $\begin{array}{l}\text { de nakna tjejerna på herrtidningens } \\
\text { mittuppslag }\end{array}$ & $\begin{array}{l}\text { en praktisk kille som renoverade huset } \\
\text { själv }\end{array}$ \\
\hline han pejlade in varenda tjej i lokalen & $\begin{array}{l}\text { en stor kille på en racer körde om ho- } \\
\text { nom }\end{array}$ \\
\hline
\end{tabular}




\begin{tabular}{|c|c|}
\hline $\begin{array}{l}\text { det är ofta svårt att rekrytera tjejer till } \\
\text { de tekniska programmen }\end{array}$ & $\begin{array}{l}\text { killarna skulle gå på diskotek och ragga } \\
\text { brudar }\end{array}$ \\
\hline ordet "tjej" är lånat från romani & han är en reko kille \\
\hline en salt tjej & ranta efter killer \\
\hline en skarp tjej & $\begin{array}{l}\text { en del killar tycker att det är skämmigt } \\
\text { att gå till ungdomsmottagningen }\end{array}$ \\
\hline hans tjej är så skön & "Skärpning nu, killar!" ropade tränaren \\
\hline en snygg tjej & $\begin{array}{l}\text { hon slog upp när hon träffade en annan } \\
\text { kille }\end{array}$ \\
\hline $\begin{array}{l}\text { han började genast stöta på den snygg- } \\
\text { aste tjejen }\end{array}$ & en snygg kille \\
\hline $\begin{array}{l}\text { han tafsade på en tjej i krogkön och fick } \\
\text { en spark i skrevet tillbaka }\end{array}$ & hennes nye kille är en riktig snygging \\
\hline tjejerna hade tajta jeans & $\begin{array}{l}\text { han spöade upp killen som muckade gräl } \\
\text { med honom på puben }\end{array}$ \\
\hline killar och tjejer & hon strular med två killar \\
\hline den snyggaste tjejen i klassen & en städad kille \\
\hline $\begin{array}{l}\text { tjejerna tar över det ena chefsjobbet ef- } \\
\text { ter det andra }\end{array}$ & en kille med sug i blicken \\
\hline hans nya tjej & $\begin{array}{l}\text { killarnas snack var späckat med svordo- } \\
\text { mar }\end{array}$ \\
\hline $\begin{array}{l}\text { en torr tjej som aldrig ville gå på disko- } \\
\text { tek }\end{array}$ & $\begin{array}{l}\text { killarna har börjat tagga upp inför kva- } \\
\text { let }\end{array}$ \\
\hline $\begin{array}{l}\text { en kille och två tjejer bildade kvällens } \\
\text { första triangel }\end{array}$ & $\begin{array}{l}\text { en teknisk kille som alltid lagar bilen } \\
\text { själv }\end{array}$ \\
\hline $\begin{array}{l}\text { tjejerna har tuffat till sig och vågar säga } \\
\text { sin mening }\end{array}$ & $\begin{array}{l}\text { en kille och två tjejer bildade kvällens } \\
\text { första triangel }\end{array}$ \\
\hline
\end{tabular}




\begin{tabular}{ll}
\hline hans tjej var alltid villig & $\begin{array}{l}\text { killar i tonåren är ofta utagerande och } \\
\text { aggressiva }\end{array}$ \\
en tjej på sexton vårar & $\begin{array}{l}\text { en kille i gänget som alltid försöker spela } \\
\text { översittare }\end{array}$ \\
en ärtig tjej & \\
\hline
\end{tabular}

KONTAKT

Emma Sköldberg

Institutionen för svenska språket, Göteborgs universitet

emma.skoeldberg@svenska.gu.se 